\title{
The Efficacy Study of Snake Fruit (Salacca edulis Reinw Var. Bong- kok) Extract as Skin Lightening Agent
}

\author{
Astrid Tilaar ${ }^{1,2}$, Anna Ranti $^{2}$, Abdul Mun'im ${ }^{1 *}$
}

\begin{abstract}
Introduction: The whitening skin product market has been growing significantly in Asia Pacific. Indonesia is one of those countries that mainly think that having a white color skin is simply beautiful. Therefore, it motivates Indonesian women to buy more whitening product for their beauty needs. Objective: The purpose of this research is to find raw material for whitening product from Indonesian plants that can be useful as skin lightening agents. This study investigated the potential of snake fruit (Salacca edulis Reinw var. Bongkok) ethanolic extract as skin lightening agent. Fruits of Salacca edulis Reinw contains flavonoids which have been reported to play a part in skin depigmentation. Methods: A randomized double-blind study on 17 human volunteers showed marked skin lightening effects using cream containing $3 \%$ extract as there was a significant reduction in skin melanin index which compared favorably with the base cream $(p<0,05)$. Results: The result strongly suggested that snake fruit ethanolic extract can be used as raw material for skin lightening agents and therefore Indonesia dependency on imported raw materials could be reduced.
\end{abstract}

Key words: Antioxidant, Melanin index, Salacca edulis Reinw, Tyrosinase, Snake fruit extract

\section{Astrid Tilaar ${ }^{1,2}$, Anna Ranti $^{2}$, Abdul Mun'im ${ }^{1 *}$ \\ 'Department of Pharmacognosy- Phytochemistry, Faculty of Pharmacy, Universitas Indonesia, Depok 16424, Indonesia \\ ${ }^{2}$ Martha Tilaar Innovation Centre, Jakarta, Indonesia}

\section{Correspondence}

\section{Abdul Mun'im}

Department of Pharmacognosy - Phytochemistry, Faculty of Pharmacy, Universitas Indonesia, Depok 16424, Indonesia Phone: +6221-7270031

Email: munim@farmasi.ui.ac.id

\section{History}

- Submission Date: 21-12-2016;

- Review completed: 05-01-2017;

- Accepted Date: 11-01-2017.

DOI : 10.5530/pj.2017.2.39

Article Available online http://www.phcogj.com/v9/i1

\section{Copyright}

(C) 2017 Phcog.Net. This is an openaccess article distributed under the terms of the Creative Commons Attribution 4.0 International license.

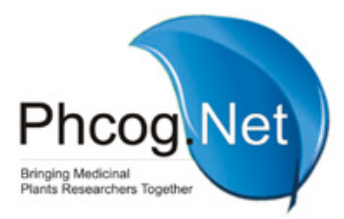

\section{INTRODUCTION}

Indonesian assumes having lighter skin is beautiful. It associated with the perception that having lighter skin is something prettier and nicer. It motivates Indonesian women to use skin-lightening product. ${ }^{1}$

Melanin synthesis was the major source of skin color and played an important role in protection of $\mathrm{UV}^{2}$ Although many mechanistic points could be targeted, tyrosinase inhibition is the most common approach to achieve skin whitening effect. Ingredients such as hydroquinone, ascorbic acid, and retinoic acid are used as whitening agents to lighten the skin. However, despite their benefits, these whitening agents would cause some harmful side effects resulting in limited application. Therefore, there is an increased interest in whitening agents obtained from natural products since plants are known to be a rich source of bioactive chemicals, are mostly free from harmful side effects. ${ }^{3}$ Recently, there is ongoing effort to search for tyrosinase inhibitor from them. ${ }^{4}$

Natural whitening products that inhibit tyrosinase can roughly be differentiated into two categories, simple phenols, and polyphenols. Flavonoids belong to the best-studied group of plant polyphenols. They are used in numerous natural medical treatments because of a number of beneficial effects such as anticancer, anti-inflammatory, and protection against UV. Some of these effects are based on the modulation of the immune system, but others are related to the antioxidant and ROS scavenger capacities and the possibility to chelate metals at the active site of metalloenzymes. They can also have hypopigmented effects, as they can directly inhibit tyrosinase and can act on the distal part of the melanogenesis oxidative pathway. ${ }^{5}$

Snake fruit (Salacca edulis Reinw) belongs to the class of Salacca originated from South East Asia. There are many snake fruit cultivars in Indonesia; it is well known in Java, Sumatera, and another island. There is some variety of snake fruit such as Manonjaya, Bongkok, Banjarnegara, Condet, Pondoh, Bali, Enrengkang, and Sidempuan. Most of the snake fruit have an astringent taste and are not sweet. Snake fruit (Salacca edulis Reinw.) var. Bongkok, which grows in Sumedang Regency, West Java, are considered as unfavorable fruit and wasted product. However, it contains flavonoid, alkaloid, terpenoid, tannin, and quinine compound groups, but not saponin. In 2003, the harvested snake fruit var. Bongkok decreased by $24 \%$, leading to near extinction. ${ }^{6}$ Several studies have reported about total polyphenol and antioxidant activity of snake fruit, however study on its inhibition of tyrosinase activity and its efficacy as skin lightening agents in human skin had not been done. This study investigated the potential of snake as skin lightening agent.

\section{MATERIAL AND METHODS}

\section{Materials}

The snake fruit (Salacca edulis Reinw) var. Bongkok was collected from Conggeang a sub-district of Sumedang, West Java, Indonesia. The flesh of snake fruit was macerated in ethanol $96 \%$ and kept in a 
container for 3 days before it was filtered. The filtrates were evaporated at $40^{\circ} \mathrm{C}$.

\section{Antioxidant Activity Assay}

The DPPH radical scavenging activity was evaluated according to the procedure in the previous study. ${ }^{7}$ The extract solution $(0.5 \mathrm{ml})$ in methanol and $\mathrm{L}(+)$ ascorbic acid in demineralized water was added in DPPH methanol solution. The reaction mixture was incubated for 30 minutes at room temperature $\left(37^{\circ} \mathrm{C}\right)$. The absorbance was measured at $517 \mathrm{~nm}$ using a spectrophotometer (UV-1601 Shimadzu). L(+) ascorbic acid was used as positive control. The concentration of sample extract was measured at $1 \%, 3 \%$, and $5 \%$. Inhibition of DPPH free radical in percent (\%) $\% \mathrm{DPPH}=\frac{A c-A s}{A c} \times 100 \%$

Where $A_{c}$ is the absorbance of the control reaction (containing all reagents except the sample extract) and $\mathrm{A}_{\mathrm{s}}$ is the absorbance of the sample extract.

\section{Tyrosinase Inhibition Activity Assay}

This assay was performed using methods similar to the previous study with L-tyrosine as a substrate. ${ }^{8}$ The sample extract solution and hydroquinone diluted with phosphate buffer then added with L-tyrosine. The mixture was incubated for 60 minutes at room temperature $\left(37^{\circ} \mathrm{C}\right)$ and absorbance was measured at $475 \mathrm{~nm}$ (UV-1601 Shimadzu). The extracts were tested at the concentrations at $1 \%, 3 \%$, and 5\%. Hydroquinone, which was used as positive control was also tested at concentrations at $1 \%, 3 \%$, and $5 \%$. The percentage tyrosinase inhibition was calculated as follows:

$\%$ inhibition $=\frac{[(A b-(A t-A o)]}{A b} \times 100$

Where $\mathrm{Ab}$ is the absorbance of the control reaction (containing all reagents except the sample extract), At is the absorbance of the sample extract with tyrosinase and Ao is the absorbance of the sample extract without tyrosinase enzyme.

\section{Clinical Study \\ Design}

After receiving approval from Ethics Committee of Research and Development of the Indonesian Ministry of Health, the clinical study was performed as a randomized double-blind study.

Methods

Each randomly chosen subjects were given 2 different creams to be applied twice daily. One cream was base (no extract) and the other was the tested formula containing 3\% snake fruit ethanolic extract. Each cream was marked with "right" or "left" indicating application of that cream to the respective forearms. The skin melanin index was measured with Mexameter MX 16 (Courage-Khazaka, Cologne, Germany ) at day 0 (baseline), 14 days and 28 days. Three mexameter readings per test site (inner forearms) were taken during each visit and the average was recorded as the final mexameter reading, per test site.

Subjects

The study protocol was approved by Ethics Committee of Research and Development of Indonesian Ministry of Health. Informed consent was explained to the patients by investigators and they agreed to participate by signing a written consent form. 17 subjects were selected for the study using the following criteria. Inclusion criteria were 18-45 years old women having a healthy and normal skin, exhibiting darker skin with melanin index ranging from 483-588 units, signing the informed consent, not using other daily topical products, and not wearing long sleeves shirt during the clinical trials period. Exclusion criteria were subjects with skin disorders, breastfeeding, menopause, smoker and used topical products that interfere skin condition in their daily use.

\section{Statistical Analysis}

The data was presented in terms of mean and SD, analyzed by analytical t-test statistics using the SPSS statistical software package. The p-value of less than 0.05 was considered, statistically significant.

\section{RESULTS AND DISCUSSION}

\section{Antioxidant Activity Assay}

The result showed that snake fruit ethanolic extract has a high antioxidant activity. The scavenging effects of the ethanolic extracts from Salacca edulis Reinw on DPPH radicals increased with increasing concentrations. Comparison of potency antioxidant activity of ethanolic extracts with ascorbic acid at various concentrations shown in Figure 1. In Figure 1, ascorbic acid assumed to have baseline antioxidant potency thus noted to have $100 \%$ antioxidant effect. The $5 \%$ concentration of the extract showed the strongest antioxidant activity ( $99,5 \%$ antioxidant potency compared to ascorbic acid). The $1 \%$ concentration to $3 \%$ concentration significantly increased compared than 3\% concentration to $5 \%$ concentration of the extract. The result was similar to a previous study that reported snake fruit as a tropical fruit that is rich in antioxidants. ${ }^{9}$ The antioxidant activities of the extracts (using DPPH assay) were highly correlated with total phenolic and moderately correlated with flavonoid content. ${ }^{10}$

\section{Tyrosinase Inhibition Activity Assay}

The tyrosinase inhibition activity increased with increasing concentration of snake fruit ethanolic extract which is reported in Figure 2. Hydroquinone was set as the baseline and thus assigned 100\% tyrosinase inhibition activity.The ethanolic extract with $5 \%$ concentration showed the highest tyrosinase inhibition activity $(18,71 \%$ potency when compared to hydroquinone's tyrosinase inhibition activity) as shown in Figure 2. The reason for this results is that some studies reported flavonoid had the capability to inhibit tyrosinase activity but those of compounds from the flavanol group were still limited. Snake fruit extract contains epicatechin, one of flavanol group substituents. Batubara et al showed that epicatechin had tyrosinase inhibition activity. ${ }^{11}$

However, compared with hydroquinone, tyrosinase inhibition of snake fruit ethanolic extract was extremely low. This could be related to the current paper decision to use crude extract, and thus there were other components that may still be in the extract and affect this activity.

\section{Efficacy Study}

Statistical analysis with t-test showed no significant differences in skin melanin index with base cream ( $\mathrm{p}>0.05)$.

The cream containing snake fruit ethanolic extract showed the significant differences in skin melanin index with t-test statistical analysis $(\mathrm{p}<0.001)$. The result is similar to the paper by Kiefer et al. that shows skin melanin index was reduced by snake fruit ethanolic extract. Considering that the study concluded that flavonoid from various citrus extracts was very effective in brightening the skin tone, it means that flavonoid from snake fruit ethanolic extracts might play a role in decreasing human skin melanin index ${ }^{12}$ (Table 1 and 2).

Statistical analysis with t-test showed the significant differences in skin melanin index between base cream and ethanolic extract cream $(p<0.05)$ that shown in Table 3. 


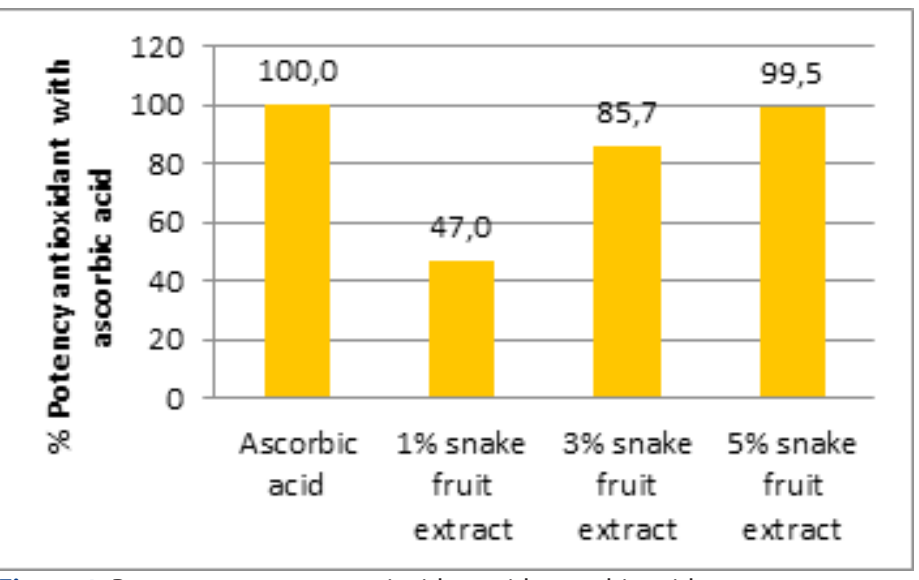

Figure 1: Percentage potency antioxidant with ascorbic acid.

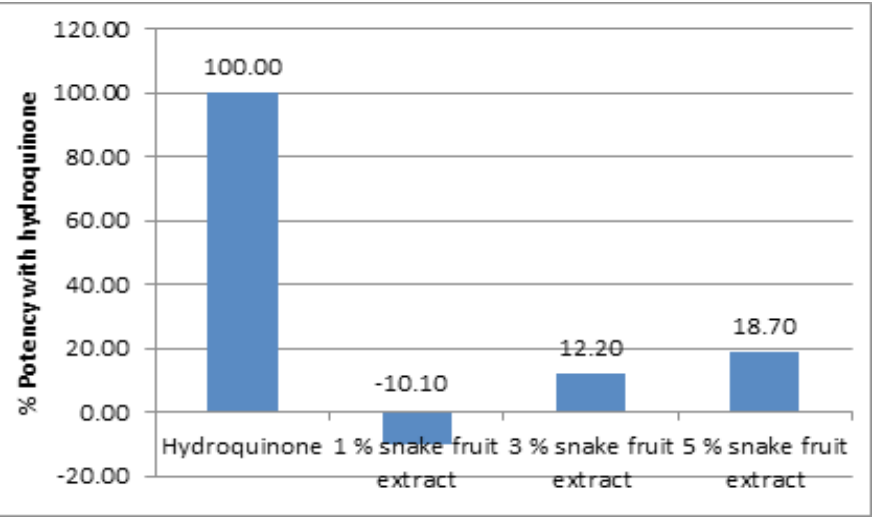

Figure 2: Percentage potency tyrosinase inhibition with hydroquinone.

Table 1: Comparison between early melanin index and final melanin index in base cream group

\begin{tabular}{ccccc}
\hline Melanin index & Mean & SD & P value & N \\
\hline Early melanin index & 528,31 & 21,05 & 0,115 & 17 \\
Final melanin index & 527,37 & 20,03 & & \\
\hline
\end{tabular}

Table 2: Comparison between early melanin index and final melanin index in ethanolic extract cream group

\begin{tabular}{ccccc}
\hline Melanin index & Mean & SD & P value & N \\
\hline Early melanin index & 526,1 & 22,05 & $<0,001$ & 17 \\
Final melanin index & 522,37 & 21,12 & & \\
\hline
\end{tabular}

Table 3: Comparison between skin melanin index base cream and ethanolic extract cream group

\begin{tabular}{ccccc}
\hline Melanin index & Mean & SD & P value & N \\
\hline $\begin{array}{c}\text { Ethanolic extract } \\
\text { cream }\end{array}$ & 522,37 & 21,12 & $<0,05$ & 17 \\
Base cream & 527,37 & 20,03 & & \\
\hline
\end{tabular}

\section{CONCLUSION}

The current paper is concluded that ethanolic extract of snake fruit have high antioxidant activity at $1 \%, 3 \%$, and $5 \%$ concentrations. Furthermore, in terms of tyrosinase inhibition activity, snake fruit ethanolic extract have inhibition activity at only $3 \%$ and $5 \%$ concentration. The current paper also reported that cream containing snake fruit ethanolic extract were able to reduce melanin index after 28 days of application. This suggested that snake fruit ethanolic extract can be used as a raw material for skin lightening agents thus opening new avenues for future research and development.

\section{ACKNOWLEDGMENT}

Thanks to PT Martina Berto for facility to perform this study.

\section{CONFLICT OF INTEREST}

None

\section{ABBREVIATIONS USED}

DPPH: 2,2'-Diphenyl-1-picryl hydrazyl; ROS: Reactive oxygen species

\section{REFERENCES}

1. Hanna A, Putih Cantik Persepsi Kecantikan dan Obsesi Orang Indonesia untuk Memiliki Kulit Putih, Malang. 2007.

2. Lin JY, Fisher DE. Melanocyte Biology and Skin Pigmentation. Nature Journal. 2007;445:843-50. https://doi.org/10.1038/nature05660 PMid:17314970.

3. Lin J, Chiang H, Lin Y, Wen K. Natural Products with Skin-Whitening Effects. Journal of Food and Drug Analysis. 2007;16:1-10.

4. Parvez S, Kang M, Chung HS, Bae H, Naturally Occurring Tyrosinase Inhibitors: Mechanism and Applications in Skin Health, Cosmetics, and Agriculture Industries. Journal of Phytotherapy Research. 2007:21:805-16. https://doi. org/10.1002/ptr.2184 PMid:17605157.

5. Solano F, Briganti S, Picardo M, Ghanem G. Hypopigmenting Agents: An Updated Review on Biological, Chemical, and Clinical Aspects. Pigment. Cell Res. 2006;19:550-71.https://doi.org/10.1111/j.1600-0749.2006.00334.x PMid:17083484.

6. Afrianti LH, Sukandar EY, Ibrahim S, Adnyana IK. Antihyperuricemic Effect of Ethanol Extract of Snake Fruit (Salacca edulis Reinw.) var. Bongkok on Wista Male Rat. J. Food Sci. Eng. 2012;2:271-6.

7. Shimada K, Fujikawa K, Yahara K, Nakamura T. Antioxidative Properties of Xanthan on the Autoxidation of Soybean Oil in Cyclodextrin Emulsion. J. Agric. Food Chem. 1992;40:945-8. https://doi.org/10.1021/jf00018a005.

8. Tilaar M, Wong LW, Ranti AS, Wasitaatmadja SW, Suryaningsih, Junardy FD, Maily. In Search of Naturally Derived Whitening Agent-Pragmatic Approach, Asian Societies of Cosmetic Scientists $8^{\text {th }}$ Conference ASCS 2007. Delivering Science to the Depths of Asian Skin, Singapore. 2007;116-7.

9. Leong LP, Shui G. An Investigation of Antioxidant Capacity of Fruits in Singapore Markets, Journal of Food Chemistry. 2002;103:1003-8. https://doi.org/10.1016/ s0308-8146(01)00251-5.

10. Aralas S, Mohamed M, Bakar A. Antioxidant Properties of Selected Salak (Salacca zalacca) varieties in Sabah, Malaysia. Journal of Nutrition and Food Science. 2009;39:243-50. https://doi.org/10.1108/00346650910957492.

11. Batubara I, Darusman LK, MitsunagaT, Aoki H, Rahminiwati M, Djauhari E, Yamuchi K. Flavonoid from Intsia palembanica as Skin Whitening Agent. Journal of Biological Sciences. 2011;11:475-80. https://doi.org/10.3923/jbs.2011.475.480.

12. Kiefer S, Weibel M, Smits J, Juch M, Tiedke J, Herbst N. Citrus flavonoids with Skin Lightening Effects-Safety and Efficacy Studies. SOFW-Journal 2010:136(12):1-6

\section{ABOUT AUTHORS}

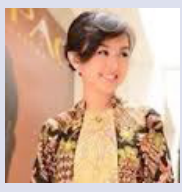

Astrid Tilaar: Is graduated from Graduate Program of Herbal Medicine, Faulty of Pharmacy, Universitas Indonesia. Currently she is $\mathrm{P}$ consultant and beauty practitioner.

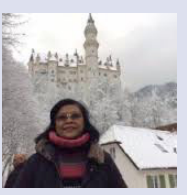

Anna Ranti: Is founder of PT Assetra Inno Medikos (Cosmetic manufacture). Lecturer in Cosmeticology, Parfumery and Aromatherapy, Safety and Efficacy of Cosmetic 


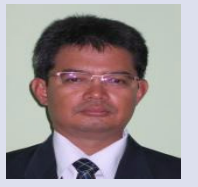

Abdul Mun'im: Ph.D., Associate Professor at Departement Pharmacognosy-Phytochemistry, Faculty of Pharmacy, Universitas Indonesia (UI) Depok, West Java, Indonesia. He has experience in the area of Pharmacognosy and Phytochemistry, working in drugs discovery of herbal plants, extraction technology, Metabolite profiling, Structure Elucidation, and Degenerative Diseases (such as diabetes mellitus, antihypertension, and cholesterol).

Cite this Article: Tilaar A, Ranti A, Mun'im A. The Efficacy Study of Snake Fruit (Salacca edulis Reinw Var. Bongkok) Extract as Skin Lightening Agent. Pharmacogn J. 2017;9(2):235-8. 